\title{
Efek Antihistamin Ekstrak Daun Jambu Biji (Psidium guajava) pada Tikus Putih (Rattus norvegicus) dengan Diinduksi Ovalbumin
}

\author{
Wahyu Tri Kawuri' ${ }^{1}$, Ratih Dewi Yudhani², Novan Adi Setyawan ${ }^{3}$ \\ 1. Program Studi Kedokteran Fakultas Kedokteran, Universitas Sebelas Maret \\ 2. Laboratorium Farmakologi Fakultas Kedokteran, Universitas Sebelas Maret \\ 3. Laboratorium Patologi Anatomi Fakultas Kedokteran, Universitas Sebelas Maret
}

Korespondensi: kawuriwahyutri@gmail.com

\begin{abstract}
ABSTRAK
Pendahuluan: Data World Allergy Organization (WAO) tahun 2013 menunjukkan bahwa prevalensi alergi diperkirakan sekitar $30-40 \%$ dari populasi dunia. Reaksi alergi terjadi akibat pelepasan histamin oleh sel mast. Pengobatan alergi jangka panjang selama ini memiliki efek samping berupa ganggun kardiovaskuler, retensi urin, Acute Generalized Exanthematous Pustulosis (AGEP), dan gangguan saraf. Penelitian sebelumnya menunjukkan kuersetin mampu menghambat pelepasan histamin oleh sel mast. Pada analisis kimia, daun jambu biji mengandung kuersetin. Penelitian ini bertujuan untuk mengetahui efek antihistamin ekstrak daun jambu biji (Psidium guajava) pada tikus putih (Rattus norvegicus) yang diinduksi ovalbumin.

Metode: Penelitian true experimental design dengan metode posttest only group design menggunakan 24 tikus putih (Rattus norvegicus) yang dibagi kedalam 6 kelompok secara acak. Kelompok kontrol normal (KN) tanpa perlakuan, kontrol negatif (K-) yang hanya diinduksi ovalbumin, kontrol positif $(\mathrm{K}+)$ diberikan metilprednisolon, dan kelompok perlakuan (P1, P2, P3) diberikan ekstrak daun jambu biji dengan dosis, berikut $27 \mathrm{mg} / 200$ gramBB, $54 \mathrm{mg} / 200$ gramBB, dan $108 \mathrm{mg} / 200$ gramBB. Pengamatan efek antihistamin berupa perhitungan rata-rata jumlah garuk tikus. Data dianalisis dengan menggunakan uji One-Way ANOVA dan dilanjutkan uji Post Hoc Tukey.

Hasil: Hasil uji One-Way ANOVA menunjukkan perbedaan rata-rata jumlah garuk tikus antar kelompok perlakuan bermakna secara statistik $(\mathrm{p}=0,00)$. Berdasarkan hasil uji Tukey, kelompok KN $(2,25 \pm 0,96)$ dibandingkan dengan kelompok K- $(45,75 \pm 5,50)$ menunjukan peningkatan rata-rata jumlah garuk yang bermakna secara statistik $(\mathrm{p}=0,00)$. Hasil rata-rata jumlah garuk tikus pada kelompok P2 $(9,00 \pm 0,82)$ dibandingkan dengan kelompok KN $(2,25 \pm 0,96)$ tidak menunjukan perbedaan yang bermakna secara statistik $(\mathrm{p}=0,085)$.

Kesimpulan: Ekstrak daun jambu biji (Psidium guajava) memiliki efek antihistamin pada tikus putih (Rattus norvegicus) yang diinduksi ovalbumin.
\end{abstract}

Kata Kunci: efek antihistamin; ekstrak daun jambu biji; induksi ovalbumin; jumlah garuk; kuersetin

ABSTRACT

Introduction: Data from the World Allergy Organization (WAO) in 2013 showed that the prevalence of allergies is estimated at around 30-40\% of the world population. Allergic reactions occur due to histamine release by mast cells. Long-term allergy treatment has side effects in the form of cardiovascular disorders, urinary retention, Acute Generalized Exanthematous Pustulosis (AGEP), and nervous disorders. Previous studies showed quercetin was able to inhibit histamine release by mast cells. In chemical analysis, guava leaves contain quercetin. This study aims to determine the effect of antihistamine extract of guava leaves (Psidium guajava) on white mouse (Rattus norvegicus) induced by ovalbumin. 


\begin{abstract}
Methods: The quasi experimental design with the posttest only group design method used 24 mice which were randomly divided into 6 groups. Normal control group $(K N)$, negative control (K-) was only induced by ovalbumin, positive control $(K+)$ was given methylprednisolone, and treatment group $(P 1, P 2, P 3)$ was given a guava leaf extract with a dose, $27 \mathrm{mg} / 200 \mathrm{gramBW}, 54 \mathrm{mg} / 200 \mathrm{gramBW}$, and $108 \mathrm{mg} / 200 \mathrm{gramBW}$. Observation of the effects of antihistamines in the form of calculating the average number of scratched mice. Data were analyzed using the One-Way ANOVA test and followed by Tukey Post Hoc test.

Results: The results of the One-Way ANOVA test showed differences in the mean number of mouse between treatment groups were statistically significant $(p=0.00)$. Based on the results of the Tukey test, the KN group $(2.25 \pm 0.96)$ compared with the K-group $(45.75 \pm$ 5.50) showed differences in the average number of scratched mouse which were significantly statistics $(p=0.00)$. The results of the average number of mouse in the KN group $(2.25 \pm 0.96)$ compared to $P 2(9.00 \pm 0.82)$ showed no difference that was statistically significant $(p=0.085)$.

Conclusion: Guava leaf extract (Psidium guajava) has an antihistamine effect in white mouse (Rattus norvegicus) on ovalbumin-induced.
\end{abstract}

Keywords: antihistamine effect; guava leaves extract; ovalbumin induced; number of scratched, quercetin

\section{PENDAHULUAN}

Reaksi alergi atau hipersensitivitas merupakan reaktivitas khusus dari kepekaan host terhadap suatu alergen berdasarkan proses imunologi yang timbul pada kontak ke dua atau berikutnya ${ }^{1}$. Alergi merupakan kondisi kronis dengan keterlibatan sistemik yang dapat menyebabkan disfungsi kekebalan tubuh dan mendasari timbulnya penyakit tidak menular lainnya ${ }^{2}$.

Data World Allergy Organization (WAO) tahun 2013 menunjukan bahwa prevalensi alergi di dunia diperkirakan sekitar $30-40 \%$ dari populasi dunia. Manifestasi alergi yang terjadi seperti asma, rhinokonjungtivitis, dermatitis atopi atau eksem, dan anafilaksis jumlahnya mengalami peningkatan setiap tahunnya $^{2}$. Di dunia diperkirakan terdapat sekitar 334 juta populasi penderita asma dan terdapat sekitar $2,5 \%$ populasi tersebut terdapat di Indonesia ${ }^{3}$.

Manajemen alergi selama ini tergantung pada kepatuhan penderita dalam menghindari faktor pemicu serta pengobatan alergi yang digunakan untuk memblokade mediator utama sehingga menurunkan efek alergi yang meluas ${ }^{4}$. Berdasarkan Keputusan Menteri Kesehatan Republik Indonesia No.
HK.01.07/MENKES/395/2017 tentang Daftar Obat Esensial Nasional menyatakan bahwa obat antialergi yang tersedia di puskesmas dan rumah sakit meliputi, deksametason, difenhidramin, epinefrin (adrenalin), klorfeniramin, loratadin, dan cetirizine ${ }^{5}$.

Difenhidramin, klorfeniramin, loratadin, dan cetirizine termasuk obat golongan antihistamin yang dapat menyebabkan efek samping pada penggunaan jangka panjang. Penggunaan difenhidramin, klorfeniramin, loratadin, dan cetirizine dapat menyebabkan gangguan pada sistem konduksi kardiovaskuler, retensi urin akut, acute generalized exanthematous pustulosis (AGEP), penurunan fungsi kognitif dan gangguan neuromuscular junction ${ }^{6,7}$. Dengan demikian diperlukan upaya pencarian obat alternatif untuk alergi dengan menggunakan tanaman obat.

Daun jambu biji (Psidium guajava L.) adalah salah satu dari tanaman di Indonesia yang sering dijadikan sebagai tanaman obat. Tanaman tersebut memiliki kemampuan terapeutik sebagai antiinflamasi, antioksidan, antitumor, antispasmodik, dan antiemetik ${ }^{8}$. Hasil ekstraksi daun jambu biji (Psidium guajava L.) dengan campuran hidroetanol 
didapatkan kandungan senyawa kuersetin ${ }^{9}$. Hasil studi in vitro, kandungan kuersetin pada ekstrak bawang Bombay (Allium cepa) yang diinjeksikan kepada tikus yang diinduksi ovalbumin memiliki efek antialergi dengan mekanisme stabilisasi membran sel mast, menghambat aktivitas eosinofil peroksidase dan protein dalam Broncho Alveolar Lavage Fluid (BALF), serta menghambat pelepasan histamin, leukotrien, prostaglandin D2, dan sitokin inflamasi lainnya ${ }^{10}$.

Berdasarkan uraian diatas diperlukan suatu upaya pengembangan obat alternatif antialergi. Ekstrak daun jambu biji (Psidium guajava) yang mengandung kuersetin diharapkan memiliki efek antihistamin yang berperan sebagai obat antialergi. Penelitian ini bertujuan untuk mengetahui efek antihistamin ekstrak daun jambu biji (Psidium guajava) pada tikus putih (Rattus norvegicus) yang diinduksi dengan ovalbumin.

\section{METODE}

Penelitian true experimental design dengan menggunakan desain penelitian posttest only control group design. Penelitian dilakukan di Laboratorium Farmakologi Fakultas Kedokteran Universitas Sebelas Maret dengan menggunakan hewan uji tikus putih jantan. Penelitian ini untuk mengetahui efek antihistamin ekstrak daun jambu biji berbagai dosis pada tikus putih yang diinduksi ovalbumin dengan menilai rata-rata jumlah garuk tikus.

Sampel penelitian berupa 24 tikus putih jantan (Rattus norvegicus) dengan berat berkisar 200-300 gram. Tikus dibagi menjadi enam kelompok secara acak. Kelompok kontrol normal (KN) tanpa perlakuan. Kelompok kontrol negatif (K-) hanya diinduksi ovalbumin. Kelompok kontrol positif $(\mathrm{K}+)$ diberikan metilprednisolon $0,072 \mathrm{mg} / 200$ gramBB $^{18,20}$. Kelompok perlakuan (P1, P2, P3) diberikan ekstrak daun jambu biji dengan dosis sebagai berikut: $27 \mathrm{mg} / 200$ gramBB, 54 $\mathrm{mg} / 200 \quad$ gramBB, dan $108 \mathrm{mg} / 200$ $\operatorname{gramBB}^{19,20}$.

Pembuatan ekstrak daun jambu biji (Psidium guajava) menggunakan metode maserasi dengan pelarut etanol $70 \%$ yang dilakukan di Laboratorium Farmasi Universitas Setia Budi, Surakarta.

Adaptasi hewan uji terhadap lokasi penelitian dilakukan selama seminggu (hari ke1 sampai hari ke-7) dengan memberikan pakan standar secara rutin. Sensitisasi ovalbumin menggunakan suspensi $0,1 \%$ ovalbumin dalam $\mathrm{Al}(\mathrm{OH})_{3} 10 \%$ sebagai adjuvant yang dilarutkan dalam akuades. Pemberian ovalbumin secara subkutan dengan volume $0,5 \mathrm{ml} / 200$ gramBB tikus putih di belakang leher ${ }^{11}$. Induksi ovalbumin dilakukan setiap 2 hari sekali (hari ke-8 sampai hari ke-14).

Pemberian metilprednisolon $(0,072$ $\mathrm{mg} / 200$ gramBB) dilarutkan dalam $2 \mathrm{ml}$ akuades dilakukan secara peroral menggunakan spuit oral sebelum diinduksi ovalbumin hari ke-14. Pemberian ekstrak daun jambu biji (27 mg/200 gramBB, 54 mg/200 gramBB, dan $108 \mathrm{mg} / 200$ gramBB) dilarutkan dalam $2 \mathrm{ml}$ akuades dilakukan secara peroral menggunakan spuit oral. Pemberian ekstrak daun jambu biji setiap sebelum diinduksi ovalbumin (hari ke-8 sampai hari-14).

Pengamatan efek antihistamin pada tikus yang diinduksi ovalbumin adalah efek penurunan reaksi alergi yang diukur melalui pengamatan dan perhitungan rata-rata jumlah garuk tikus ${ }^{12}$. Pengamatan garuk dilakukan pada lokasi induksi ovalbumin selama satu $\mathrm{jam}^{13}$. Pengamatan efek antihistamin dilakukan pada hari ke-14 mulai menit ke-30 setelah perlakuan.

\section{HASIL}

Hasil pengamatan akan ditampilkan pada Tabel 1.

Tabel 1. Data Rata-rata Jumlah Garuk Tikus

Kelompok Rata-rata Jumlah Garuk \pm SD




\begin{tabular}{lc}
\hline $\mathrm{KN}$ & $2,25 \pm 0,96$ \\
$\mathrm{~K}-$ & $45,75 \pm 5,50$ \\
$\mathrm{~K}+$ & $12,25 \pm 3,11$ \\
$\mathrm{P} 1$ & $17,50 \pm 3,79$ \\
$\mathrm{P} 2$ & $9,00 \pm 0,82$ \\
$\mathrm{P} 3$ & $15,25 \pm 2,99$ \\
\hline
\end{tabular}

Rata-rata jumlah garuk tikus menunjukkan data terdistribusi normal dengan uji Shapiro-Wilk $(\mathrm{p}>0,05)$ dan data homogen dengan uji Levene $(\mathrm{p}=0,054)$. Hasil uji analisis One-Way ANOVA menunjukan adanya perbedaan rata-rata jumlah garuk tikus di antara kelompok perlakuan yang signifikan secara statistik $(\mathrm{p}=0,000)$.

Uji Tukey dilakukan untuk mengetahui letak perbedaan yang bermakna di antara kelompok tersebut. Hasil uji Tukey disajikan pada Tabel 2.

Tabel 2. Hasil Uji Tukey Data Rata-rata Jumlah Garuk Tikus

\begin{tabular}{lccccc}
\hline \multicolumn{1}{c}{ Kelompok } & $\mathrm{K}-$ & $\mathrm{K}+$ & $\mathrm{P} 1$ & $\mathrm{P} 2$ & $\mathrm{P} 3$ \\
\hline KN & 0,000 & 0,004 & 0,000 & 0,085 & 0,000 \\
K- & & 0,000 & 0,000 & 0,000 & 0,000 \\
K+ & & & 0,306 & 0,665 & 0,839 \\
P1 & & & & 0,019 & 0,922 \\
P2 & & & & & 0,126 \\
P3 & & & & &
\end{tabular}

Keterangan:

$\mathrm{KN}$ : kelompok kontrol normal

$\mathrm{K}-\quad$ : kelompok kontrol negatif

$\mathrm{K}+$ : kelompok kontrol positif

P1 : kelompok perlakuan 1

P2 : kelompok perlakuan 2

P3 : kelompok perlakuan 3

\section{PEMBAHASAN}

Berdasarkan hasil penelitian, rata-rata jumlah garuk tikus pada kelompok kontrol normal, tanpa perlakuan $(2,25 \pm 0,96)$ lebih rendah dibandingkan dengan kelompok kontrol negatif dengan induksi ovalbumin $(45,75 \pm 5,50)$ yang menunjukan perbedaan signifikan secara statistik $(\mathrm{p}=0,000)$. Hasil penelitian ini sesuai dengan penelitian LaMotte yang menyatakan pemberian histamin pada tikus mampu menimbulkan manifestasi reaksi alergi berupa gerakan garuk $^{15}$. Hal ini menunjukan bahwa pemberian induksi ovalbumin pada tikus mampu menimbulkan reaksi alergi yang ditandai dengan peningkatan rata-rata jumlah garuk tikus dibandingkan kelompok kontrol normal. Ovalbumin merupakan protein yang mampu membantu pelepasan histamin oleh sel mast. Pelepasan histamin inilah yang akan menimbulkan reaksi alergi ${ }^{11}$.

Berdasarkan hasil Uji Tukey yang disajikan pada Tabel 2, menyatakan bahwa rata-rata jumlah garuk tikus pada kelompok kontrol negatif (induksi ovalbumin) lebih tinggi dibandingkan dengan kelompok perlakuan dengan berbagai dosis ekstrak daun jambu biji. Perbedaan rata-rata jumlah garuk tikus menunjukan hasil yang signifikan secara statistik. Hal ini menunjukan bahwa pemberian ekstrak daun jambu biji mampu menekan reaksi alergi yang ditandai dengan penurunan rata-rata jumlah garuk tikus dibandingkan dengan kelompok kontrol negatif. Pada hasil analisis kimia menunjukan daun jambu biji mengandung kuersetin ${ }^{9}$. Kuersetin merupakan salah satu senyawa flavonoid yang berperan sebagai antihistamin. Pada hasil studi in vitro pada tikus putih yang diinduksi ovalbumin secara inhalasi, kuersetin yang terkandung didalam ekstrak bawang Bombay memiliki efek antihistamin dengan mekanisme stabilisasi sel mast sehingga menghambat 
pelepasan histamin ${ }^{16}$. Dengan demikian, pemberian ekstrak daun jambu biji yang mengandung kuersetin pada tikus yang diinduksi ovalbumin kemungkinan mampu menimbulkan efek antihistamin melalui mekanisme stabilisasi sel mast. Hasil penelitian ini didukung oleh penelitian yang dilakukan Yong Wong Jang melalui pemberian intraperitoneal ekstrak gingseng merah Korea pada tikus yang diinduksi ovalbumin secara subkutan di bagian leher. Pemberian ekstrak gingseng merah Korea yang mengandung kuersetin mampu menurunkan rata-rata jumlah garuk tikus yang diinduksi ovalbumin ${ }^{13}$.

Hasil rata-rata jumlah garuk tikus pada kelompok perlakuan dengan ekstrak daun jambu biji dosis pertama, $27 \mathrm{mg} / 200$ gramBB $(17,50 \pm 3,79)$ lebih tinggi dibandingkan dengan kelompok perlakuan dengan ekstrak daun jambu biji dosis kedua, $54 \mathrm{mg} / 200$ gramBB $(9,00 \pm 0,82)$. Perbedaan rata-rata jumlah garuk tikus menunjukan hasil yang signifikan secara statistik $(\mathrm{p}=0,019)$. Hal ini menunjukan bahwa peningkatan dosis ekstrak daun jambu biji semakin menekan reaksi alergi yang ditandai dengan rata-rata jumlah garuk tikus pada kelompok perlakuan dosis kedua lebih rendah dari kelompok perlakuan dosis pertama. Hasil penelitian ini sejalan dengan penelitian Yong Wong Jang pada tahun 2015 yang memberikan tiga variasi dosis ekstrak gingseng merah Korea pada tikus yang diinduksi ovalbumin menunjukan peningkatan dosis semakin menekan reaksi alergi yang ditandai dengan penurunan rata-rata jumlah garuk tikus ${ }^{16}$.

Hasil rata-rata jumlah garuk tikus pada kelompok perlakuan ekstrak daun jambu biji dosis kedua, $54 \mathrm{mg} / 200$ gramBB $(9,00 \pm 0,82)$ lebih rendah dibandingkan dengan kelompok perlakuan ekstrak daun jambu biji dosis ketiga, $108 \mathrm{mg} / 200$ gramBB $(15,25 \pm 2,99)$, meskipun perbedaan rata-rata jumlah garuk tikus tidak signifikan secara statistik $(\mathrm{p}=0,126)$. Hal ini menunjukan penambahan dosis ekstrak daun jambu biji dari dosis kedua menjadi dosis ketiga justru mengakibatkan penurunan efek antihistamin yang ditandai dengan rata-rata jumlah garuk tikus pada kelompok perlakuan dosis tiga lebih tinggi dibandingkan dengan kelompok perlakuan dosis kedua. Receptor Occupancy Theory menyatakan bahwa efek maksimal obat timbul ketika seluruh reseptor telah ditempati obat. Kelebihan dosis obat dapat menyebabkan terbentuknya obat bebas. Hal ini terjadi karena konsentrasi obat melebihi konsentrasi yang dibutuhkan untuk menempati seluruh reseptor ${ }^{17}$. Akumulasi obat bebas di dalam tubuh yang terlalu banyak dapat mengakibatkan penurunan efek obat bahkan dapat mengakibatkan toksisitas ${ }^{1}$. Oleh karena itu, pada kelompok perlakuan dengan ekstrak daun jambu biji dosis kedua (54 mg/200 gramBB) kemungkinan seluruh reseptor telah ditempati sehingga pada kelompok perlakuan dosis ketiga (108 $\mathrm{mg} / 200$ gramBB) kemungkinan telah terbentuk zat bebas di dalam tubuh tikus yang mengakibatkan penurunan efek antihistamin.

Hasil rata-rata jumlah garuk tikus pada kelompok kontrol normal $(2,25 \pm 0,96)$ lebih rendah dibandingkan dengan kelompok perlakuan ekstrak daun jambu biji dosis pertama, $27 \mathrm{mg} / 200$ gramBB $(9,00 \pm 0,82)$ maupun dosis ketiga, $108 \mathrm{mg} / 200$ gramBB $(15,25 \pm 2,99)$. Perbedaan rata-rata jumlah garuk tikus menunjukan hasil yang signifikan secara statistik $(\mathrm{p}=0,000)$. Hal ini menunjukan pada pemberian ekstrak daun jambu biji dosis pertama kemungkinan belum mampu menekan reaksi alergi secara optimal yang ditandai dengan rata-rata jumlah garuk tikus pada kelompok kontrol normal masih memiliki perbedaan yang signifikan dengan kelompok perlakuan dosis pertama. Pada pemberian ekstrak daun jambu biji ketiga kemungkinan sudah melebihi dosis optimal ekstrak daun jambu biji sehingga menyebabkan penurunan efek antihistamin seperti yang telah dijelaskan sebelumnnya.

Hasil rata-rata jumlah garuk tikus pada kelompok perlakuan dengan ekstrak daun jambu biji dosis kedua, $54 \mathrm{mg} / 200$ gramBB 
$(9,00 \pm 0,82)$ lebih tinggi dibandingkan dengan kelompok kontrol normal $(2,25 \pm 0,96)$ tidak menunjukan perbedaan rata-rata jumlah garuk tikus yang signifikan secara statistik $(\mathrm{p}=0,085)$. Hal tersebut menunjukan pada pemberian ekstrak daun jambu biji dosis kedua kemungkinan mampu menekan reaksi alergi secara optimal yang ditandai dengan rata-rata jumlah garuk tikus pada kelompok perlakuan dosis kedua tidak terdapat perbedaan yang signifikan secara statistik dengan kelompok kontrol normal. Oleh karena itu, pada penelitian ini kemungkinan pemberian ekstrak daun jambu biji dosis $54 \mathrm{mg} / 200$ gramBB merupakan dosis yang paling optimal dalam menurunkan rata-rata jumlah garuk tikus yang diinduksi ovalbumin.

Hasil rata-rata jumlah garuk tikus pada kelompok kontrol positif dengan pemberian metilprednisolon $(12,50 \pm 3,11)$ lebih rendah dibandingkan dengan kelompok kontrol negatif $(45,75 \pm 5,50)$ menunjukan perbedaan yang signifikan secara statistik $(\mathrm{p}=0,000)$. Hal ini menunjukan pemberian obat metilprednisolon mampu menekan reaksi alergi yang ditandai dengan penurunan ratarata jumlah garuk tikus dibandingkan kelompok kontrol negatif. Metilprednisolon menghambat pelepasan histamin melalui stabilisasi sel mast sehingga tidak menimbulkan reaksi alergi ${ }^{1}$.

Pada penelitian ini, hasil rata-rata jumlah garuk tikus pada kelompok kontrol positif $(12,50 \pm 3,11)$ lebih tinggi dibandingkan dengan kelompok kontrol normal $(2,25 \pm 0,96)$. Perbedaan rata-rata jumlah garuk tikus menunjukan hasil yang signifikan secara statistik $(\mathrm{p}=0,004)$. Hal ini menunjukan metilprednisolon belum mampu menekan reaksi alergi secara optimal yang ditandai dengan rata-rata jumlah garuk tikus pada kelompok kontrol positif masih terdapat perbedaan yang signifikan secara statistik dengan kelompok kontrol normal. Hal tersebut kemungkinan dapat terjadi karena metilprednisolon yang digunakan pada penelitian ini berupa obat dagang, bukan obat murni. Obat tablet merupakan sediaan padat dimana zat aktif diberikan bahan tambahan farmasetik yang sesuai dalam bentuk pipih dengan kedua permukaannya rata atau cembung ${ }^{17}$. Pada manusia dewasa dosis metiprednisolon peroral adalah $4 \mathrm{mg}^{18}$. Dosis metilprednisolon yang diberikan pada tikus adalah $0,072 \mathrm{mg} / 200$ gramBB. Pada penelitian ini, penggunaan obat tablet dagang metilprednisolon yang dijual bukan murni metilprednisolon $4 \mathrm{mg}$. Obat yang digunakan tidak menjelaskan secara jelas komposisi bahan tambahanya. Pada proses penelitian, ketika diberikan dosis $0,072 \mathrm{mg} / 200$ gramBB kandungan metilprednisolon kemungkinan tidak mencapai dosis tersebut karena ada bahan tambahan lainnya yang tidak diketahui kadarnya. Oleh karena itu, pemberian metilprednisolon pada penelitian ini kemungkinan menyebabkan penekanan reaksi alergi menjadi tidak optimal.

Berdasarkan hasil analisis data yang disajikan pada Tabel 2, pada kelompok perlakuan dengan berbagai dosis ekstrak daun jambu biji dibandingkan dengan kelompok kontrol positif dengan metilprednisolon tidak menunjukan perbedaan rata-rata jumlah garuk tikus yang signifikan secara statistik. Hal ini menunjukan pemberian ekstrak jambu biji kemungkinan memiliki kemampuan dalam menekan reaksi alergi sama seperti kemampuan metilpredisolon yang ditandai dengan tidak adanya perbedaan rata-rata jumlah garuk tikus yang signifikan secara statistik. Hasil ini sejalan dengan pembahasan yang telah disampaikan di atas. Kandungan kuersetin yang terdapat pada daun jambu biji kemungkinan mampu menekan reaksi alergi melalui mekanisme stabilisasi sel mast, sehingga menghambat pelepasan histamin. Inhibisi pelepasan histamin ini yang tidak menimbulkan reaksi alergi berupa garuk.

\section{KESIMPULAN}


Ekstrak daun jambu biji (Psidium guajava) memiliki efek antihistamin pada tikus putih (Rattus norvegicus) yang diinduksi ovalbumin. Hal ini ditandai dengan penurunan jumlah garuk tikus pada kelompok perlakuan dengan ekstrak daun jambu biji. Pemberian ekstrak daun jambu biji dosis $54 \mathrm{mg} / 200$ gramBB memiliki efek antihistamin yang lebih baik dibandingkan dengan dosis 27 mg/200 gramBB dan 108 mg/200 gramBB.

\section{UCAPAN TERIMA KASIH}

Penulis menyampaikan terimakasih kepada Siti Ma'rufah, M.Sc., Apt., yang telah memberikan kritik dan saran selama penelitian hingga proses penulisan naskah publikasi ini dan Bapak Sukidi, selaku petugas Laboratorium Histologi FK UNS yang membantu proses penelitian.

\section{DAFTAR PUSTAKA}

1. Indijah SW, Fajri P. Farmakologi. Jakarta: Kementerian Kesehatan RI; 2016. 2092017 p.

2. WAO. White Book on Allergy [Internet]. Pawankar R, Canonica GW, Holgate ST, Blaiss MS, editor. Wisconsin: World Allergy Organization; 2013. 1-248 p. Diambil dari: http://www.worldallergy.org/UserFiles/file /WhiteBook2-2013-v8.pdf

3. The Global Asthma Network. The Global Asthma Report 2014 [Internet]. Auckland: GAN; 2014. 14-16 p. Diambil dari: http://www.globalasthmareport.org/resour ces/Global_Asthma_Report_2014.pdf

4. EAACI. Global Atlas of Allergy [Internet]. Zurich: The European Academy of Allergy and Clinical Immunology; 2014. Diambil dari:

http://www.eaaci.org/globalatlas/GlobalAt lasAllergy.pdf

5. Kemenkes RI. Keputusan Menteri Kesehatan RI No. HK.01.07/MENKES/395/2017 tentang Daftar Obat Esensial. 2017 hal. 1-48.

6. Church MK, Maurer M, Simons FER, Bindslev-Jensen C, Van Cauwenberge P, Bousquet $\mathrm{J}$, et al. Risk of first-generation H1-antihistamines: A GA2LEN position paper. Allergy: European Journal of
Allergy and Clinical Immunology. 2010;65(4):459-66.

7. Walsh GM. Antihistamines (H1 receptor antagonists) [Internet]. 1 ed. Side Effects of Drugs Annual. Elsevier B.V.; 2014. 295307 p. Diambil dari: http://linkinghub.elsevier.com/retrieve/pii/ B9780444626356000152

8. Bose D, Chatterjee S. Biogenic synthesis of silver nanoparticles using guava (Psidium guajava) leaf extract and its antibacterial activity against Pseudomonas aeruginosa. Applied Nanoscience [Internet]. Springer Berlin Heidelberg; 2016;6(6):895-901. Diambil dari: http://link.springer.com/10.1007/s13204015-0496-5

9. Díaz-de-Cerio E, Gómez-Caravaca AM, Verardo V, Fernández-Gutiérrez A, Segura-Carretero A. Determination of guava (Psidium guajava L.) leaf phenolic compounds using HPLC-DAD-QTOF-MS. Journal of Functional Foods [Internet]. Elsevier Ltd; 2016;22:376-88. Diambil dari:

http://dx.doi.org/10.1016/j.jff.2016.01.040

10. Mlcek J, Jurikova T, Skrovankova S, Sochor J. Quercetin and its anti-allergic immune response. Molecules. 2016;21(5):1-15.

11. Leasa BN. Pemberian Ovalbumin Sebagai Penyebab Alergi pada Marmot. Bogor; 2010.

12. Takeuchi S, Yasukawa F, Furue M, Katz SI. Collared mice: A model to assess the effects of scratching. Experimental Dermatology. 2012;40(6):1301-15.

13. Jang Y, Lee WJ, Hong GS, Shim WS. Red ginseng extract blocks histaminedependent itch by inhibition of H1r/TRPV1 pathway in sensory neurons. Journal of Ginseng Research [Internet]. Elsevier Ltd; 2015;39(3):257-64. Diambil dari: http://dx.doi.org/10.1016/j.jgr.2015.01.004

14. Sugiyono. Statistik Untuk Penelitian. Mulyatiningsih E, editor. Bandung: CV Alfabeta; 2007.

15. LaMotte RH, Shimada SG, Sikand P. Mouse models of acute, chemical itch and pain in humans. Experimental Dermatology. 2011;20(10):778-82.

16. Oliveira TT, Campos KM, Cerqueira-Lima AT, Carneiro TCB, Da Silva Velozo E, Melo ICAR, et al. Potential therapeutic effect of Allium cepa L. and quercetin in a murine model of Blomia tropicalis induced asthma. DARU, Journal of Pharmaceutical Sciences. 2015;23(1):1-12. 
Kawuri et al., Efek Antihistamin Ekstrak Daun Jambu Biji (Psidium guajava) pada Tikus Putih (Rattus norvegicus) yang Diinduksi Ovalbumin

17. Murtini G. Farmasetika Dasar. Jakarta: Kementerian Kesehatan RI; 2016.

18. Azis AL. Penggunaan Kortikosteroid di Klinik (The use of corticosteroid in clinics). Surabaya; 2006.

19. Kemenkes RI, (2017). Formularium Ramuan Obat Tradisional Indonesia. Indonesia.

20. Laurence, D.R., Bacharach, A.L., (1964).

Evaluation of Drug Activities:

Pharmacometrics, Evaluation of Drug Activities. Academic Press, New York. 